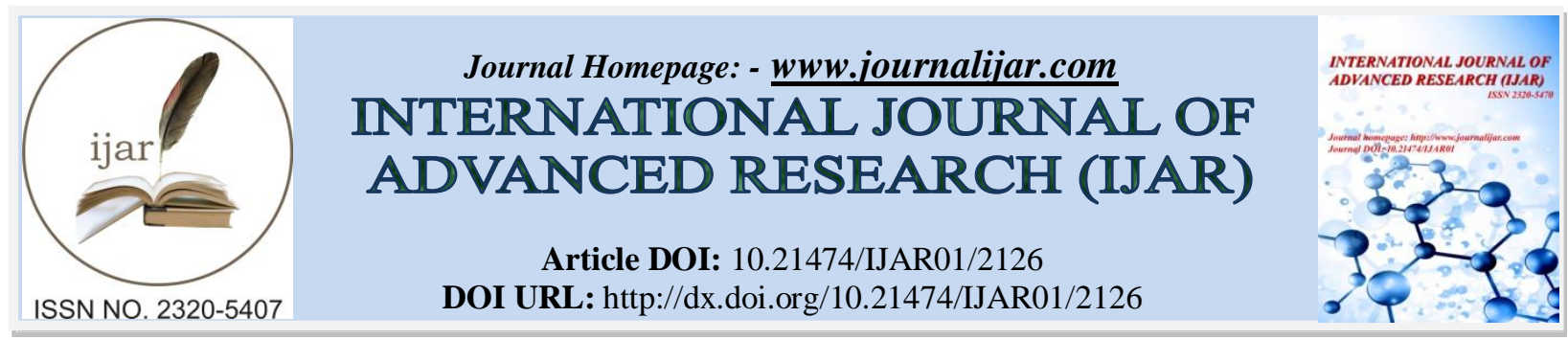

RESEARCH ARTICLE

\title{
HETEROSIS IN OBCORDATE LEAF CMS BASED HYBRIDS IN PIGEONPEA [CAJANUS CAJAN (L.) MILLSP.].
}

"Parsagoni Mallesh ${ }^{1,2}$, H. C. Nanda ${ }^{1}$ and C. V. Sameerkumar"

1. Department of Genetics and Plant Breeding, Indira Gandhi Agricultural University, Raipur-492012, Chhattisgarh, India.

2. International Crops Research Institute for the Semi-Arid Tropics (ICRISAT), Patancheru-5023241.

\section{Manuscript Info}

\section{Manuscript History}

Received: 25 September 2016

Final Accepted: 27 October 2016

Published: November 2016

Key words:-

Heterosis, Restorer, mid parent heterosis, better parent, heterosis and standard check.

\begin{abstract}
An experiment was conducted in Randomized Complete Block Design (RBD) with $14 \mathrm{~F}_{1}$ hybrids, $4 \mathrm{~B}$-lines, $5 \mathrm{R}$-lines and 5 standard checks of pigeonpea sown on 14 July 2015 at ICRISAT, Patancheru.The results on heterosis of 14 pigeonpea hybrids over mid-parent, better parent, and the standard check for seed yield and yield components revealed that the maximum heterosis over mid parent fallowed by better parent and standard check. Among these, seed yield $(\mathrm{kg} / \mathrm{ha})$ was recorded higher heterosis followed by number of secondary branches plant ${ }^{-1}$ and number of pods plant ${ }^{-1}$. Further, ICPH 4679, ICPH 4571 and ICPH 4746 hybrids had uniformly recorded desirable heterosis over mid parent, better parent and standard check. ICPL 20116, ICPL 20093 R lines, ICPB 2204, and ICPB 2200 B lines were observed to be superior for seed yield and other important yield attributes in the present study and are recommended for use in hybrid pigeonpea breeding programmes.
\end{abstract}

Copy Right, IJAR, 2016,. All rights reserved.

\section{Introduction:-}

Pigeonpea [Cajanus cajan (L.) Millsp.]is an important food legume crop grown mainly in tropics and sub-tropics under rainfed agriculture by resource-poor farmers because crop is cultivated with low inputs.As world population increasing demand of protean also increase especially in India, where most of the people are vegetarian.Pigeonpea seeds have 20-22\% protein and are used as green peas, whole grain or split peas (Saxena et al., 2002).In India, pigeonpea is cultivated in 264.02 lakh ha with average productivity of $789 \mathrm{~kg} / \mathrm{ha}$ (Department of Agriculture and Cooperation, Ministry of Agriculture, Government of India, 2013-14). Indicates further need for improving its yield potential.Recently, Saxena and Nadarajan (2010) have reported 25 to $156 \%$ of seed yield over the best inbred variety.Considering the importance of hybrids an attempt was made to estimate the extent of different level of heterosis for seed yield in newly developed obcordate leaf CMS based pigeonpea hybrids and estimation of available heterosis in pigeonpea.

\section{Materials and methods:-}

The material consisting of $14 \mathrm{~F}_{1}$ hybrids, 4 B-lines, 5 R-lines along with five standard checks were evaluated in a randomized complete block design with three replications. The experimental materials were sown at International Crops Research Institute for the Semi-Arid Tropics (ICRISAT), Patancheru, on July 14, 2015. The plot size for each $\mathrm{F}_{1}$ hybrid, B-lines and R-lines was two rows. Two-row plots were planted with $4 \mathrm{~m}$ length with inter and intra row 
spacing of 75 and $50 \mathrm{~cm}$, respectively. Border rows were planted around the experimental plot to increase the precision of study and to reduce border effect. All recommended agronomic practices were followed for parents and hybrids to keep the crop in good condition. Necessary and need based plant protection measures were also taken up to obtain better crop.

\section{Results and discussion:- \\ Days to 50\% flowering:-}

Among 14 hybrids, ICPH 4748 (-7.536\%), ICPH 4606 (-7.826\%), ICPH 4573 (-15.384\%), ICPH 4680 (-0.314\%), ICPH 4572 (-6.289\%), ICPH 4683 (-3.773\%), ICPH 4682 (-7.547\%) and ICPH 4567 (-10.105\%) showed negative desirable heterosis for days to $50 \%$ flowering over better parent. The range of heterobeltiosis for days to $50 \%$ flowering was from $-15.384 \%$ (ICPH 4573) to $-0.314 \%$ (ICPH 4680). For relative heterosis, out of 14 hybrids, 10 hybrids showed desirable negative heterosis of which, ICPH $4573(-14.655 \%)$ recorded with the highest negative heterosis followed by ICPH 4572 (-10.911\%). However, ICPH 4746 (4.715\%), ICPH 4564 (1.960\%), ICPH $4571(0.846 \%)$ and ICPH $4679(0.314 \%)$ exhibited positive heterosis. The relative heterosis for days to $50 \%$ flowering ranged from $-14.655 \%$ (ICPH 4573) to 4.715\% (ICPH 4746). All the hybrids showed negative heterosis for days to 50\% flowering over standard check variety, Asha. Among these, five hybrids ICPH $4682(-16.239 \%)$, ICPH 4567 (-15.099\%), ICPH 4571 (-15.099\%), ICPH 4602 (-15.099\%) and ICPH 4683 (-12.821\%) were significantly earlier than the standard check and the rests were on par. The range of standard heterosis varied from $16.239 \%$ (ICPH 4682) to 7.407\% (ICPH 4602). All the hybrids had desirable negative heterosis for days to $50 \%$ flowering. Among these, hybrids ICPH 4682, ICPH 4573, ICPH 4567, ICPH 4571, and ICPH 4683 were the top five hybrids with significant negative heterosis. Early to flower and mature is a desirable trait in hybrid pigeonpea in escaping drought and ensuring high yield. Based on the present research findings, the hybrid ICPH 4682 ranked first in higher negative heterosis indicating the presence of exploitable hybrid vigour for early flowering. Wankhade et al. (2005) also reported significant negative heterosis for days to 50\% flower in the hybrids based on genetic malesterility system where as Sarode et al. (2009) investigated significant negative heterosis in long duration pigeonpea.Kandalkar (2007) and Shoba and Balan (2010) reported significant negative heterosis in CMS based hybrids showing preference for the early flowering hybrids.

\section{Days to maturity:-}

Negative heterosis in days to maturity over different levels of heterosis is a desirable heterosis for early maturity. Among all the 14 hybrids, the significant negative heterosis over better parent was observed in eleven hybrids. Among these, hybrid ICPH $4748(-9.980 \%)$ showed the highest negative value followed by ICPH $4602(-8.889 \%)$, ICPH 4606 (-6.042\%) and ICPH 4567 (-3.68\%). Almost all the hybrids showed negative heterosis except three hybrids viz., ICPH 4571, ICPH 4588 and ICPH 4680 for positive heterosis for days to maturity was observed. The negative heterosis over mid parent was observed in 13 out of 14 hybrids. One hybrid ICPH $4680(0.658 \%)$ showed positive heterosis with mid parent. The range of relative heterosis varied from $-7.771 \%$ (ICPH 4748 ) to $-0.662 \%$ (ICPH 4571). All the hybrids manifested significant negative heterosis for days to maturity over the check variety Asha and Maruti. ICPH 4746 (-12.103\%) was the earliest to mature followed by ICPH 4572 (-11.905), ICPH 4567 (-11.706), ICPH 4571 (-10.714\%), ICPH 4606 (-10.516\%) and ICPH 4683 (-10.119\%), respectively.Heterosis for days to maturity ranged from -9.980 to $1.119 \%,-7.771$ to $-0.439 \%$ and 12.103 to $-8.929 \%$ over better, mid and standard parent respectively.Extent of negative heterosis for days to maturity was reported by Chaudhari (1979) and Pandey and Singh (2002). The crosses maturing early involved at least one early maturing parent. Phad (2003) and Kandalkar (2007), Sarode et al. (2009), and Shoba and Balan (2010) also reported similar results on heterosis in pigeonpea.

\section{Plant height:-}

For plant height the hybrids viz., ICPH 4606 (19.574), ICPH 4748 (15.887), ICPH 4573 (-13.050), ICPH 4588 (11.915), ICPH $4682(-2.974 \%)$ and ICPH $4602(-1.727 \%)$ recorded with the negative heterobeltiosis. Moreover, eight hybrids ICPH 4564 (9.326\%), ICPH 4572 (6.947\%), ICPH 4679 (6.736\%), ICPH 4746 (5.348\%), ICPH 4571 (5.088\%), ICPH 4683 (2.760\%), ICPH 4567 (2.281\%), and ICPH 4680 (1.796\%) showed positive heterosis for plant height. Out of 14 hybrids nine hybrids, ICPH 4564 (10.183\%), ICPH 4572 (7.955), ICPH 4679 (7.384), ICPH 4746 (6.747), ICPH 4571 (6.299), ICPH 4683 (3.835), ICPH 4567 (2.461), ICPH 4602 (2.987) and ICPH 4680 (1.709\%) showed positive heterosis over mid parent for plant height. Five hybrids viz., ICPH 4748, ICPH 4606, ICPH 4573, ICPH 4588 and ICPH 4682 exhibited negative heterosis for plant height over mid parent in plant height (Table 4.12). The range of relative heterosis for plant height varied from $10.183 \%$ (ICPH 4564) to -7.879\% (ICPH 4606). All hybrids manifested significant positive heterosis over standard check Asha. In these ICPH 4564 (14.258\%) 
showed highest positive value followed by ICPH 4572 (13.897), ICPH 4588 (12.092\%), ICPH 4679 (11.550) and ICPH 4746 (8.771\%) for plant height, respectively.Heterosis for plant height ranged from $-19.574 \%$ to $9.326 \%$ for heterobeltiosis, $-7.879 \%$ to $10.183 \%$ for relative heterosis and $0.179 \%$ to $14.258 \%$ for standard heterosis, respectively.Several workers including Solomon et al. (1957), Singh (1971), Sharma et al. (1973), Veeraswamy et al. (1973), Chaudhari (1979), Jain, and Saxena (1990) reported significant positive heterosis for plant height. Pandey and Singh (2002) reported negative standard heterosis for plant height in pigeonpea. The negative heterosis in the context of breeding dwarf genotype will be desirable. However, laterWankhade et al. (2005), Sarode et al. (2009), and Shoba and Balan (2010) also reported significant positive heterosis for plant height.

\section{Number of primary branches plant ${ }^{-1}:-$}

The 14 hybrids under study showed positive heterosis for number of primary branches plant ${ }^{-1}$ over better parent. In these ICPH 4606 (26.184\%) exhibited the high positive heterosis for number of primary branches plant-1 over better parent followed by ICPH 4679 (20.675\%), ICPH 4683 (17.460\%) and ICPH 4564 (16.580\%). The range of heterobeltiosis for number of primary branches plant ${ }^{-1}$ varied from $26.675 \%$ (ICPH $26.184 \%$ ) to $0.000 \%$ (ICPH 4680). Fourteen out of 14 hybrids recorded positive heterosis for number of primary branches plant ${ }^{-1}$ over mid $^{2}$ parent. Among these, ICPH 4606 (36.296\%) was the high positive heterosis over mid parent and ICPH 4571 $(1.905 \%)$ showed the lowest positive heterosis over mid parent for number of primary branches plant ${ }^{-1}$. The range of relative heterosis for number of primary branches plant ${ }^{-1}$ varied from $36.296 \%$ (ICPH 4606) to $1.905 \%$ (ICPH 4571). Out of 14 hybrids, two hybrids were had negative heterosis over standard check and the rest 12 hybrids manifested positive heterosis for number of primary branches plant ${ }^{-1}$. Among these, ICPH $4572(22.832 \%)$ was the high positive heterosis over standard check and followed by ICPH 4564 (16.581\%), ICPH 4683 (15.643\%) and ICPH 4679 (15.018\%) showed significant positive heterosis for number of primary branches plant ${ }^{-1}$ over standard variety Asha. Two hybrids ICPH $4682(-3.422 \%)$ and ICPH $4680(-1.547 \%)$ recorded negative heterosis for number of primary branches plant ${ }^{-1}$ over Asha.Among the 14 hybrids, all are manifested positive heterosis over mid, better parents and standard variety, respectively. Except ICPH 4682 (-3.422\%) and ICPH $4680(-1.547 \%)$ where these two hybrids showed negative heterosis for number of primary branches plant ${ }^{-1}$ over standard check variety Asha. For the number of primary branches plant ${ }^{-1}$, the range of heterosis over better parent, mid parent and standard check was from $26.676 \%$ to $0.000 \%, 36.296 \%$ to $1.905 \%$ and $22.832 \%$ to $-3.422 \%$, respectively.Solomon et al. (1957) also reported significant negative heterosis for branches, likewise Chaudhary (1979), Narladkar and Khapre (1996), Pandey and Singh (2002), Wankhade et al. (2005), and Sarode et al. (2009) also in agreement with the present findings. However, Shoba and Balan (2010) reported significant positive and negative heterosis in CMS/GMS based pigeonpea hybrids.

\section{Number of secondary branches plant ${ }^{-1}:-$}

Out of 14 hybrids, twelve showed significant positive heterosis for number of secondary branches plant ${ }^{-1}$ over better parent. In these, ICPH $4748(30.492 \%)$ was noted with the highest positive heterosis for number of secondary branches plant $^{-1}$ and followed by ICPH 4564 (26.101\%), ICPH 4683 (22.676\%), ICPH 4606(22.308\%) and ICPH $4602(18.333 \%)$. The range of heterobeltiosis for number of secondary branches plant ${ }^{-1}$ varied from $30.492 \%$ (ICPH 4748) to $-10.444 \%$ (ICPH 4588). All the 14 hybrids were significantly positive over mid parent. The range of relative heterosis for number of secondary branches plant ${ }^{-1}$ was from $41.199 \%$ (ICPH 4748) to 3.224\% (ICPH 4746).Standard heterosis revealed that nine hybrids showed significant positive heterosis for number of secondary branches plant $^{-1}$ over Asha. Among these ICPH 4571(18.837\%) was manifested the highest positive heterosis over Asha followed by ICPH 4573(18.606\%), ICPH 4567 (13.982\%) and ICPH 4606 (10.283\%). Five hybrids ICPH 4680 (-9.254\%), ICPH 4588 (-7.866), ICPH 4679 (-7.751\%), ICPH 4746 (-5.439\%), and ICPH $4682(-3.127 \%)$ showed negative heterosis for number of secondary branches plant ${ }^{-1}$ over the standard variety. The range of heterosis for number of secondary branches plant ${ }^{-1}$ over better, mid and standard check was from 30.492 to $-10.444 \%, 41.199$ to $3.224 \%$ and 18.837 to $-7.867 \%$ respectively.

\section{Number of pod plant ${ }^{-1}:-$}

Among 14 hybrids, five hybrids ICPH 4567 (24.369\%), ICPH 4748 (23.982\%), ICPH 4680 (22.917\%), ICPH 4571 $(17.321 \%)$ and ICPH $4573(6.675 \%)$ showed positive heterosis for number of pods plant ${ }^{-1}$ over better parent. All the hybrids were showed positive heterosis for number of pods plant ${ }^{-1}$ over mid parent. The range of relative heterosis for number of pods plant ${ }^{-1}$ was from 48.798 (ICPH 4571) to $-10.850 \%$ (ICPH 4588). All the hybrids showed significant positive heterosis for number of pods plant ${ }^{-1}$ over Asha. Among these hybrids, ICPH 4567 (113.011\%) was the highest positive heterosis over standard check Asha and followed by ICPH 4571 (101.455\%), ICPH 4748 (75.297\%), ICPH 4683 (62.830\%) and ICPH 4682 (59.502\%). The range of standard heterosis for number of pods 
plant $^{-1}$ was from 113.011 to $22.814 \%$. The range of heterosis for number of pods plant ${ }^{-1}$ was from 24.369 to $10.011 \%$ for heterobeltiosis, 48.798 to $-10.850 \%$ for relative heterosis, and 113.011 to $22.814 \%$ for standard heterosis. These observations are in agreement with findings of Singh (1971), Veeraswamy et al. (1973), Chaudhari (1979), Patel and Patel (1992), Pandey and Singh (2002) and Kandalakar (2007). Narladkar and Khapre (1996) reported that heterosis for grain yield was due to total number of pods plant ${ }^{-1}$.

\section{Number of seeds $\operatorname{pod}^{-1}:-$}

Out of 14 hybrids, ten hybrids showed negative heterosis for number of seeds pod-1 over better parent. Among these, ICPH $4748(-5.177 \%)$ was the highest over better parent followed by ICPH $4588(-4.814 \%)$, ICPH $4680(-$ $2.894 \%)$, ICPH $4588(-2.816 \%)$ and ICPH $4602(-2.148 \%)$ recorded negative heterosis for number of seeds pod ${ }^{-1}$ over better parent. Hybrids ICPH 4679 (3.641\%), ICPH 4571 (2.622\%) and ICPH 4746 (2.434\%) showed significant heterobeltiosis in positive direction. Six hybrids showed positive heterosis for number of seeds pod ${ }^{-1}$ over mid-parent. Among these, ICPH 4679 (3.933\%) was showed the highest positive heterosis for number of seeds pod ${ }^{-1}$ over mid-parent followed by ICPH 4571 (2.622\%), ICPH 4746 (2.579\%) and ICPH 4606 (1.111\%) showed positive heterosis for number of seeds pod ${ }^{-1}$ over mid-parent while eight hybrids manifested negative in relative heterosis for number of seeds pod $^{-1}$. Among these, ICPH $4588(-3.366 \%)$ was the highest negative heterosis over mid parent followed by ICPH 4573 (-2.015\%), ICPH 4748 (-1.834\%) and ICPH 4602 (1.596\%). ICPH 4679 (6.017\%) was showed the highest heterosis over standard check Asha followed by ICPH 4571 (4.680\%), ICPH 4746 (4.489\%), ICPH 4606 (4.298\%), ICPH 4572 (3.725\%) and ICPH 4567 (2.388\%) exhibited standard heterosis in positive direction for number of seeds pod ${ }^{-1}$. Two hybrids, ICPH $4680(-0.669 \%)$ and ICPH $4748(-0.287 \%)$ had showed negative heterosis for number of seeds pod $^{-1}$ but it was on par with Asha. Range of heterosis over better, mid parent and standard check varied from $3.641 \%$ to $-5.177 \%, 3.933 \%$ to $-3.366 \%$ and 6.017 to $-0.669 \%$, respectively. The number of seeds pod ${ }^{-1}$ is also an important character, which contributes to the higher yield. Wankhade et al. (2005) also reported significant positive heterosis for seeds $\operatorname{pod}^{-1}$.

\section{Number of Seeds plant $^{-1}$ :-}

Six hybrids ICPH 4567 (33.769\%), ICPH 4683 (23.615\%), ICPH 4748 (19.261\%), ICPH 4682 (8.237\%), ICPH $4573(0.511 \%)$ and ICPH $4572(0.040 \%)$ showed positive heterosis for number of seeds plant-1 over better parent. Eight hybrids ICPH 4746, ICPH 4571, ICPH 4606, ICPH 4588, ICPH 4679, ICPH 4680, ICPH 4602 and ICPH 4564 were showed negative heterosis for number of seeds plant ${ }^{-1}$ over better parent. Similarly, significant positive heterosis for number of seeds plant ${ }^{-1}$ over mid-parent was observed in all hybrids except one hybrid (ICPH 4606). Among these hybrids, ICPH 4567 (44.129\%) was recorded the highest positive heterosis over mid parent followed by ICPH 4748 (26.261\%), ICPH 4683 (22.240\%), ICPH 4571 (13.985\%), ICPH 4564 (13.945\%) and ICPH 4679 $(11.215 \%)$ for number of seeds plant ${ }^{-1}$. One hybrid ICPH 4606 showed negative relative heterosis for number of seeds plant ${ }^{-1}$. All hybrids manifested positive heterosis for number of seeds plant ${ }^{-1}$ over Asha. Among these, ICPH 4567 (100.570\%) was showed highest positive heterosis over Asha followed by ICPH 4683 (55.207\%), ICPH 4748 (49.740\%), ICPH 4682 (48.835\%), ICPH 4564 (46.052\%), ICPH 4588 (40.389\%) and ICPH 4571 (39.378\%) exhibited standard heterosis for number of seeds plant ${ }^{-1}$ in desirable direction. Heterosis for number of seeds plant ${ }^{-1}$ ranged from 33.769 to $-15.366 \%, 44.129$ to $-6.448 \%$ and 100.570 to $16.737 \%$ over better, mid and standard parent, respectively.

\section{0-seed weight:-}

ICPH 4571 (4.51\%) and ICPH 4680 (1.81\%) were exhibited positive heterosis over better parent. The rest of all the hybrids exhibited negative heterosis over better parent. Out of 14 hybrids, 12 showed negative heterosis for 100seed weight over better parent. The range of heterobeltiosis was from 4.51 (ICPH 4571) to -11.05\% (ICPH 4682). For relative heterosis, ICPH 4746, ICPH 4571, ICPH 4679, ICPH 4680, ICPH 4602, ICPH 4564 and ICPH 4683 manifested significant positive heterosis for 100 seed weight. The other tested hybrids were on par with mid-parent and showed negative heterosis for 100-seed weight. All the hybrids were exhibited negative heterosis for 100 -seed weight over standard check Asha. The range of heterosis for 100-seed weight in the present findings was from 4.51 to $-11.05 \%, 4.98$ to $-5.81 \%$ and -1.90 to $-17.62 \%$ over better, mid and standard parent respectively. The above findings are in agreement with the findings of Chaudhari (1979), Reddy et al. (1979), Manivel et al. (1999), Deshmukh et al. (2001), Wankhade et al. (2005) and Kandalkar (2007) who also reported positive standard heterosis in pigeonpea for 100 seed weight. 


\section{Biological yield plant ${ }^{-1}:-$}

Out of fourteen hybrids, 10 were recorded positive heterosis over better parent. Among these, ICPH 4683 (44.77\%) showed the highest positive heterosis for biological yield plant ${ }^{-1}$ over better parent followed by ICPH 4567 (35.06\%), ICPH 4748 (34.54\%), ICPH 4680 (17.15\%), ICPH 4571(16.28\%) and ICPH 4573 (8.21\%) showed positive heterosis and four hybrids, ICPH $4746(-3.60 \%)$, ICPH $4606(-6.47 \%)$, ICPH $4602(-1.42 \%)$ and ICPH $4572(-1.83 \%)$ had showed negative heterosis for biological yield plant ${ }^{-1}$ over better parent. The range of heterobeltiosis was from 44.77\% (ICPH 4683) to $-6.47 \%$ (ICPH 4606). Out of 14 hybrids, 11 hybrids were recorded significant positive heterosis over mid parent. Among these, ICPH $4748(56.40 \%)$ showed highest positive heterosis over mid parent followed by ICPH 4683 (47.79\%), ICPH 4567 (46.80\%), ICPH 4573 (36.85\%) and ICPH 4680 (27.71\%) recorded positive heterosis for biological yield plant $^{-1}$ over mid parent. Only three hybrids, ICPH 4602 ($0.84 \%)$, ICPH $4746(0.46 \%)$ and ICPH $4572(-0.19 \%)$ showed negative heterosis for biological yield plant ${ }^{-1}$ over mid parental value. Among fourteen hybrids, 11 were showed positive heterosis for biological yield plant $^{-1}$ over Asha. In these, ICPH 4567 (37.58\%) was recorded the highest followed by ICPH 4683 (29.15\%), ICPH 4680 (25.22\%), ICPH 4748 (20.02\%), and ICPH 4573 (19.60\%) showed positive heterosis for biological yield plant ${ }^{-1}$ over Asha. Three hybrids showed negative heterosis over the standard variety, Asha. The range of standard heterosis for biological yield plant ${ }^{-1}$ was from $37.58 \%$ (ICPH 4567) to $-10.20 \%$ (ICPH 4746). The range of heterobeltiosis for biological yield plant ${ }^{-1}$ varied from 44.77 to $-6.47 \%, 56.40$ to $-0.84 \%$ for relative heterosis, and 37.58 to $-10.20 \%$ for standard heterosis.

\section{Seed yield plant $^{-1}(\mathrm{~g})$ :-}

The range of heterobeltiosis varied from $38.85 \%$ (ICPH 4573) to $-55.88 \%$ (ICPH 4571). Out of fourteen hybrids, six hybrids showed significant positive heterosis over better parent. Among these ICPH 4573 (38.85\%) was recorded the highest heterosis over better parent followed by ICPH 4683 (32.12\%), ICPH 4572 (21.19\%), ICPH 4606 (6.78\%), ICPH $4602(2.54 \%)$ and ICPH $4748(1.20 \%)$ showed significant and positive heterosis for seed yield plant ${ }^{-}$ ${ }^{1}$ over better parent and eight hybrids, ICPH 4746, ICPH 4571, ICPH 4588, ICPH 4679, ICPH 4680, ICPH 4564, ICPH 4682 and ICPH 4567 were recorded negative heterosis for seed yield plant ${ }^{-1}$ over better parent.The relative heterosis revealed that, out of fourteen hybrids, ten hybrids, ICPH 4573 (86.08\%), ICPH 4572 (55.17\%), ICPH 4606 (51.71\%), ICPH 4683 (41.11\%), ICPH 4602 (39.96\%), ICPH 4748 (37.61\%), ICPH 4588 (19.67\%), ICPH 4680 (16.68\%), ICPH 4679 (10.98\%) and ICPH 4746 (4.26\%) exhibited relative heterosis for seed yield plant ${ }^{-1}$ in positive direction. ICPH 4567 (-27.03\%), ICPH 4571 (-23.02\%), ICPH $4564(-23.27 \%)$ and ICPH $4682(-7.12 \%)$ had showed the negative heterosis for seed yield plant $^{-1}$ over mid-parent. ICPH 4567 (38.456\%), ICPH $4683(37.022 \%)$, ICPH 4564 (24.465\%), ICPH 4571 (21.676\%), ICPH 4573 (20.166\%), ICPH 4606 (11.6241\%), ICPH 4602 (7.1922\%), ICPH 4572 (4.877\%), ICPH 4588 (4.56439\%) and ICPH $4682(3.75 \%)$ showed significant positive heterosis for seed yield plant ${ }^{-1}$ over Asha. Four hybrids ICPH 4680 (-18.83\%), ICPH 4746 (-9.901\%), ICPH 4748 ($8.414 \%)$ and ICPH $4679(-6.591 \%)$ manifested negative heterosis for seed yield plant ${ }^{-1}$ over Asha. The range of standard heterosis was from 38.456 (ICPH 4567) to $18.83 \%$ (ICPH 4680). Based on the present investigation, a wide range of positive and negative heterosis was observed in seed yield plant ${ }^{-1}$. The estimated range of heterosis over better, mid, and standard parents for seed yield plant ${ }^{-1}$ varied from 38.85 to $-55.88 \%, 86.08$ to $-27.03 \%$, and 38.456 to $-18.83 \%$, respectively.Yadav and Singh (2004), Sekhar et al. (2004) and Wankhade et al. (2005) also reported positive standard heterosis for seed yield plant ${ }^{-1}$ in pigeonpea. The positive heterosis could be useful for further exploitation (Wanjari et al., 2007).

\section{Pollen fertility \%:-}

All hybrids were exhibited negative heterosis for pollen fertility\% over better parent. Among these, ICPH 4573 $(10.561 \%)$ was recorded the highest negative heterosis for pollen fertility\% over better parent followed by ICPH 4748 (-10.493\%), ICPH 4683 (-10.147\%), ICPH 4680 (-9.801\%), ICPH 4588 (-8.544\%), ICPH 4606 (8.156\%) and ICPH 4602 (-7.447\%) showed significant negative heterosis for pollen fertility\% over better parent. The range of heterobeltiosis for pollen fertility\% was from $-10.561 \%$ (ICPH 4573) to $-0.265 \%$ (ICPH 4571).Relative heterosis, twelve hybrids ICPH 4748 (-9.239\%), ICPH 4606 (-7.995\%), ICPH 4573 (-7.009\%), ICPH 4683 (-5.743\%), ICPH 4680 (-5.21\%), ICPH 4572 (-4.289\%), ICPH 4602 (-3.867\%), ICPH 4682 (-3.844\%), ICPH 4588 (-3.387\%), ICPH $4567(-2.664 \%)$, ICPH $4679(-0.321 \%)$ and ICPH 4571(-0.068\%) manifested negative heterosis for pollen fertility\%. Two hybrids showed positive heterosis recorded in ICPH $4746(0.784 \%)$ and ICPH $4564(0.779 \%)$ over mid-parent for pollen fertility $\%$. Out of 14 hybrids, all were exhibited negative standard heterosis for pollen fertility $\%$ over standard check Asha. Among these, ICPH 4572 (-4.831\%) was recorded highest negative heterosis over mid parent followed by ICPH 4567 (-4.704\%), ICPH 4682 (-4.577\%), ICPH 4571 (-4.068\%), ICPH 4746 (1.905\%) and ICPH 4748 (-1.269\%) exhibited negative standard heterosis for pollen fertility\% over standard check. 


\section{Seed yield (kg /ha):-}

All the 14 hybrids recorded positive heterosis in desirable direction over better parent. Among these ICPH 4564 $(69.31 \%)$ was exhibited highest positive heterosis over better parent followed by ICPH 4573 (57.78\%), ICPH 4588 (41.15\%), ICPH4571 (40.72\%), ICPH 4606 (38.21\%) and ICPH 4602 (23.71\%) were noted with positive heterosis for seed yield $(\mathrm{kg} / \mathrm{ha})$ over better parent. The range of heterobeltiosis for seed yield $(\mathrm{kg} / \mathrm{ha}$ ) was from $69.31 \%$ (ICPH 4564) to $1.47 \%$ (ICPH 4567). For relative heterosis, all hybrids manifested significant positive heterosis for seed yield (kg/ha). Among these ICPH 4564 (122.99\%) was recorded the highest positive heterosis for seed yield (kg/ha) over mid parent followed by ICPH 4573 (115.73\%), ICPH 4588 (96.31\%), ICPH 4606 (79.93\%), ICPH 4571 (73.18\%), ICPH $4748(60.32 \%)$ and ICPH 4680 (54.96\%) manifested positive heterosis for seed yield (kg/ha). Out of 22 hybrids, nine ICPH 2671 (208.44\%), ICPH 2740 (121.45\%), ICPH 3477 (119.45\%), ICPH 3491 (134.17\%), ICPH 3497 (88.93\%), ICPH 3761 (102.17\%), ICPH 3933 (80.47\%), ICPH 4017 (184.9\%), ICPH 4022 (155.64\%) exhibited significant standard heterosis for seed yield (kg/ha). Two hybrids ICPH $4602(-1.23 \%)$ and ICPH 4567 ($0.81 \%$ ) showed negative heterosis for seed yield (kg/ha) over standard check.Hybrids ICPH 4746(47.41\%), ICPH 4571(37.55\%), ICPH 4748(12.3\%), ICPH 4606(10.36\%), ICPH 4573(46.01\%), ICPH 4588(37.97\%), ICPH 4679(36.05\%), ICPH 4680(14.64\%), ICPH 4572(12.69\%), ICPH 4564(65.65.49\%), ICPH 4683(6.79\%), and ICPH $4682(47.37 \%)$ exhibited positive heterosis for seed yield $(\mathrm{kg} / \mathrm{ha})$ over standard check indicating the presence of exploitable heterosis in this material of pigeonpea. In the present study, ICPH 4564 showed 69.31\% heterobeltiosis, $122.99 \%$ relative heterosis, and $65.49 \%$ standard heterosis for seed yield (kg/ha) respectively.Sekhar et al. (2004) also reported supportive standard heterosis over $40 \%$ in pigeonpea. Kandalkar (2007) reported significant positive heterosis (upto - 155.7\%) for grain yield in CMS based hybrids of pigeonpea. In general, positive and high magnitude of heterosis for grain yield was noticed and this may be due to the heterosis contributed by one or more yield contributing characters (Chandirakala et al., 2010).

\section{Harvest index:-}

Out of 14 hybrids, nine hybrids viz., ICPH 4564 (47.68\%), ICPH 4682 (44.88\%), ICPH 4606 (22.87\%), ICPH 4588 (18.41\%), ICPH 4680 (4.07\%), ICPH 4573 (3.93\%), ICPH 4683 (1.93\%), ICPH 4602 (1.84\%) and ICPH 4748 (1.10\%) exhibited positive heterosis for harvest index over standard check Asha. Five hybrids ICPH 4571 ($22.58 \%)$, ICPH 4567 (-18.09\%), ICPH 4572 (-17.59\%), ICPH 4679 (-13.59\%) and ICPH 4746 (-0.88\%) showed negative heterosis for harvest index over standard check Asha. Hybrids ICPH 4606, ICPH 4588, ICPH 4680, ICPH 4602, ICPH 4564, ICPH 4582 and ICPH 4683 exhibited positive heterosis for harvest index over mid parent, better parent and standard check indicating the presence of exploitable heterosis in pigeonpea.Out of 14 hybrids, eight hybrids viz., ICPH 4679 (-30.42\%), ICPH 4571 (-26.66\%), ICPH 4567 (-22.40\%), ICPH 4746 (-20.18\%), ICPH 4748 (-9.04\%), ICPH 4573 (-6.50\%), ICPH 4572 (-7.07\%) showed negative heterosis for harvest index over better parent. Seven hybrids viz., ICPH 4606(10.54\%), ICPH 4588(6.53\%), ICPH 4680(1.89\%), ICPH 4602(14.58\%), ICPH 4564(39.91\%), ICPH 4683(2.75\%) and ICPH 4682(16.68\%) were recorded with the positive heterosis for harvest index over better parent. Among these ICPH 4564 (39.91\%) and ICPH $4683(2.75 \%)$ showed highest and lowest positive heterosis for harvest index over better parent. The range of heterobeltiosis for harvest index varied from $-30.42 \%$ (ICPH 4679) to 39.91\% (ICPH 4564). For relative heterosis, eight hybrids viz., ICPH 4564 (57.76\%), ICPH 4682 (34.66\%), ICPH 4606 (22.85\%), ICPH 4602 (19.43\%), ICPH 4680 (15.07\%), ICPH 4588 (9.28\%), ICPH $4683(7.18 \%)$ and ICPH $4573(4.02 \%)$ manifested positive heterosis for harvest index over mid parent. Although six hybrids showed negative heterosis over mid-parent.I

\section{Dal recovery \%:-}

Eight hybrids viz., ICPH 4746 (5.80\%), ICPH 4564 (3.00\%), ICPH 4748 (2.10\%), ICPH 4567 (2.03\%), ICPH 4680 (1.49\%), ICPH 4683 (1.09\%), ICPH $4606(0.83 \%)$ and ICPH $4572(0.41 \%)$ showed positive heterosis for dal recovery \% over better parent. ICPH 4573 (-7.34\%), ICPH 4679 (-3.46\%), ICPH 4602 (-1.42\%), ICPH 4682 ($0.94 \%)$ and ICPH $4748(-0.10 \%)$ showed negative heterosis for dal recovery \% over better parent. The range of heterobeltiosis for dal recovery \% was from $-7.34 \%$ (ICPH 4573) to 5.80\% (ICPH 4746). For relative heterosis, nine hybrids ICPH 4746 (7.561\%), ICPH 4567 (5.492\%), ICPH 4564 (5.809\%), ICPH 4571 (5.105\%), ICPH 4683 $(3.288 \%)$ and ICPH $4680(3.020 \%)$ manifested significant positive heterosis for dal recovery \%. Although five hybrids showed negative heterosis for dal recovery $\%$, they were on par to mid-parent. Out of 14 hybrids, twelve hybrids viz., ICPH 4679 (-10.23\%), ICPH 4573 (-10.19\%), ICPH 4682 (-9.19\%), ICPH 4602 (-8.43\%), ICPH 4572 (-6.73\%), ICPH 4746 (-3.31\%), ICPH 4683 (-3.22\%), ICPH 4588 (-2.93\%), ICPH 4606 (-2.27\%) exhibited negative standard heterosis for dal recovery \% over check Asha. Two hybrids ICPH $4564(1.05 \%)$ and ICPH $4567(0.10 \%)$ showed positive heterosis for dal recovery \% over standard check. Hybrids ICPH 4567 and ICPH 4564 exhibited 
positive heterosis for dal recovery $\%$ over mid parent, better parent and standard check indicating the presence of exploitable heterosis in pigeonpea.

Table 1a:- Mid parent (MPH), better parent (BPH) and standard heterosis $(\mathrm{SH})$ for yield and yield components in pigeonpea hybrids

\begin{tabular}{|c|c|c|c|c|c|c|c|c|c|c|c|c|c|}
\hline & & & DFF & & & DM & 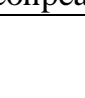 & & NPBr & & & $\begin{array}{l}\text { NScB } \\
\mathrm{r}\end{array}$ & \\
\hline $\begin{array}{l}\text { Sl. } \\
\text { No. }\end{array}$ & $\begin{array}{l}\text { Hybri } \\
\text { d }\end{array}$ & MPH & BPH & SCH & $\begin{array}{l}\text { MP } \\
\text { H } \\
\end{array}$ & $\begin{array}{l}\text { BP } \\
\text { H } \\
\end{array}$ & $\begin{array}{l}\text { SC } \\
\text { H } \\
\end{array}$ & MPH & BPH & SCH & MPH & BPH & SCH \\
\hline 1 & $\begin{array}{l}\text { ICPH } \\
4746\end{array}$ & $\begin{array}{l}4.715 \\
*\end{array}$ & 1.258 & $\begin{array}{l}- \\
8.262 \\
*\end{array}$ & $\begin{array}{l}- \\
2.20 \\
8\end{array}$ & $\begin{array}{l}- \\
2.20 \\
8\end{array}$ & $\begin{array}{l}- \\
12.1 \\
0^{*}\end{array}$ & $\begin{array}{l}11.54 \\
5^{*}\end{array}$ & $\begin{array}{l}10.62 \\
7 *\end{array}$ & $\begin{array}{l}7.204 \\
*\end{array}$ & $\begin{array}{l}3.224 \\
*\end{array}$ & $\begin{array}{l} \\
1.439\end{array}$ & $\begin{array}{l}- \\
5.439 \\
*\end{array}$ \\
\hline 2 & $\begin{array}{l}\text { ICPH } \\
4571\end{array}$ & 0.846 & 1.258 & $\begin{array}{l}- \\
15.19 \\
*\end{array}$ & $\begin{array}{l}-\bar{l} \\
0.66 \\
2\end{array}$ & $\begin{array}{l}0.67 \\
1\end{array}$ & $\begin{array}{l}- \\
10.7 \\
1 *\end{array}$ & 1.905 & 0.328 & 0.328 & $\begin{array}{l}24.99 \\
2 * *\end{array}$ & $\begin{array}{l}15.51 \\
2 * *\end{array}$ & $\begin{array}{l}18.83 \\
7 * *\end{array}$ \\
\hline 3 & $\begin{array}{l}\mathrm{ICPH} \\
4748\end{array}$ & $\begin{array}{l}- \\
9.117 \\
*\end{array}$ & $7.54 *$ & $\begin{array}{l}- \\
9.117 \\
*\end{array}$ & $\begin{array}{l}- \\
7.77 \\
1 *\end{array}$ & $\begin{array}{l}- \\
9.98 \\
*\end{array}$ & $\begin{array}{l}- \\
10.5 \\
5^{*}\end{array}$ & $\begin{array}{l}19.98 \\
9 * *\end{array}$ & $\begin{array}{l}7.619 \\
*\end{array}$ & $\begin{array}{l}5.954 \\
*\end{array}$ & $\begin{array}{l}41.19 \\
9 * *\end{array}$ & $\begin{array}{l}30.49 \\
2 * *\end{array}$ & $\begin{array}{l}9.358 \\
*\end{array}$ \\
\hline 4 & $\begin{array}{l}\text { ICPH } \\
4606\end{array}$ & $\begin{array}{l}-\overline{9} \\
9.402 \\
*\end{array}$ & $\begin{array}{l}- \\
7.826 \\
*\end{array}$ & $\begin{array}{l}- \\
9.402 \\
*\end{array}$ & $\begin{array}{l}- \\
7.77 \\
1 *\end{array}$ & $\begin{array}{l}- \\
6.04 \\
2 *\end{array}$ & $\begin{array}{l}- \\
10.5 \\
5^{*}\end{array}$ & $\begin{array}{l}36.29 \\
6 * *\end{array}$ & $\begin{array}{l}26.91 \\
8^{* *}\end{array}$ & $\begin{array}{l}15.02 \\
*\end{array}$ & $\begin{array}{l}36.77 \\
4 * *\end{array}$ & $\begin{array}{l}22.30 \\
8^{*}\end{array}$ & $\begin{array}{l}10.28 \\
3^{*}\end{array}$ \\
\hline 5 & $\begin{array}{l}\text { ICPH } \\
4573\end{array}$ & $\begin{array}{l}- \\
14.65 \\
5^{*}\end{array}$ & $\begin{array}{l}- \\
15.39 \\
* *\end{array}$ & $\begin{array}{l}- \\
15.38 \\
5^{*}\end{array}$ & $\begin{array}{l}- \\
7.77 \\
1 * \\
\end{array}$ & $\begin{array}{l}- \\
0.44 \\
2\end{array}$ & $\begin{array}{l}- \\
10.5 \\
5^{*}\end{array}$ & $\begin{array}{l}22.33 \\
3 * *\end{array}$ & $\begin{array}{l}4.872 \\
*\end{array}$ & $\begin{array}{l}14.71 \\
*\end{array}$ & $\begin{array}{l}37.25 \\
3^{* *}\end{array}$ & $\begin{array}{l}16.58 \\
4 *\end{array}$ & $\begin{array}{l}18.60 \\
6 * *\end{array}$ \\
\hline 6 & $\begin{array}{l}\text { ICPH } \\
4588\end{array}$ & $\begin{array}{l}- \\
2.034\end{array}$ & $\begin{array}{l}6.463 \\
*\end{array}$ & $\begin{array}{l}- \\
10.82 \\
6^{*}\end{array}$ & $\begin{array}{l}-7 \\
7.56 \\
7 *\end{array}$ & $\begin{array}{l}1.11 \\
9\end{array}$ & $\begin{array}{l}- \\
10.3 \\
2 *\end{array}$ & $\begin{array}{l}22.10 \\
5 * *\end{array}$ & $\begin{array}{l}8.767 \\
*\end{array}$ & $\begin{array}{l}8.767 \\
*\end{array}$ & $\begin{array}{l}5.917 \\
*\end{array}$ & $\begin{array}{l}- \\
10.44 \\
4 *\end{array}$ & $\begin{array}{l}-\bar{l} \\
7.867 \\
*\end{array}$ \\
\hline 7 & $\begin{array}{l}\text { ICPH } \\
4679\end{array}$ & 0.315 & 0.315 & $\begin{array}{l}- \\
9.117 \\
*\end{array}$ & $\begin{array}{l}- \\
1.09 \\
7\end{array}$ & $\begin{array}{l}- \\
0.44 \\
2\end{array}$ & $\begin{array}{l}- \\
10.5 \\
5^{*}\end{array}$ & $\begin{array}{l}22.66 \\
7 * *\end{array}$ & $\begin{array}{l}20.67 \\
6^{* *}\end{array}$ & $\begin{array}{l}15.02 \\
*\end{array}$ & $6.40^{*}$ & $\begin{array}{l}- \\
3.849 \\
*\end{array}$ & $\begin{array}{l}- \\
7.751 \\
*\end{array}$ \\
\hline 8 & $\begin{array}{l}\text { ICPH } \\
4680\end{array}$ & $\begin{array}{l}-\bar{l} \\
6.074 \\
*\end{array}$ & $-\overline{0.315}$ & $\begin{array}{l}- \\
9.687 \\
*\end{array}$ & $\begin{array}{l}0.65 \\
8\end{array}$ & $\begin{array}{l}0.65 \\
79\end{array}$ & $\begin{array}{l}- \\
8.92 \\
9 *\end{array}$ & $\begin{array}{l}3.270 \\
*\end{array}$ & 0.000 & $-\overline{1.547}$ & $\begin{array}{l}12.54 \\
5^{*}\end{array}$ & $\begin{array}{l}8.283 \\
*\end{array}$ & $\begin{array}{l}- \\
9.254 \\
*\end{array}$ \\
\hline 9 & $\begin{array}{l}\text { ICPH } \\
4602\end{array}$ & $\begin{array}{l}- \\
3.704 \\
*\end{array}$ & 2.201 & $\begin{array}{l}-\bar{l} \\
7.407 \\
*\end{array}$ & $\begin{array}{l}- \\
0.87 \\
7\end{array}$ & $\begin{array}{l}-\overline{8} \\
8.88 \\
9 *\end{array}$ & $\begin{array}{l}- \\
10.3 \\
2 *\end{array}$ & $\begin{array}{l}17.26 \\
5 * *\end{array}$ & $\begin{array}{l}16.25 \\
2 * *\end{array}$ & $\begin{array}{l}7.204 \\
*\end{array}$ & $\begin{array}{l}27.30 \\
6^{* *}\end{array}$ & $\begin{array}{l}18.33 \\
3^{*}\end{array}$ & $\begin{array}{l}6.699 \\
*\end{array}$ \\
\hline 10 & $\begin{array}{l}\text { ICPH } \\
4572\end{array}$ & $\begin{array}{l}- \\
10.91 \\
*\end{array}$ & $\begin{array}{l}- \\
6.289 \\
*\end{array}$ & $\begin{array}{l}- \\
15.19 \\
* *\end{array}$ & $\begin{array}{l}- \\
2.63 \\
2 *\end{array}$ & $\begin{array}{l}- \\
2.63 \\
2^{*}\end{array}$ & $\begin{array}{l}- \\
11.9 \\
1 *\end{array}$ & $\begin{array}{l}21.86 \\
1 * *\end{array}$ & $\begin{array}{l}12.30 \\
2 * *\end{array}$ & $\begin{array}{l}22.83 \\
2 * *\end{array}$ & $\begin{array}{l}14.31 \\
5^{*}\end{array}$ & 0.676 & 2.422 \\
\hline 11 & $\begin{array}{l}\mathrm{ICPH} \\
4564\end{array}$ & 1.961 & $5.66^{*}$ & $\begin{array}{l}- \\
11.11 \\
*\end{array}$ & $\begin{array}{l}- \\
0.43 \\
9\end{array}$ & $\begin{array}{l}- \\
0.43 \\
9\end{array}$ & $\begin{array}{l}- \\
9.92 \\
1 *\end{array}$ & $\begin{array}{l}21.30 \\
1 * *\end{array}$ & $\begin{array}{l}16.58 \\
1 * *\end{array}$ & $\begin{array}{l}16.58 \\
1 * *\end{array}$ & $\begin{array}{l}33.61 \\
4 * *\end{array}$ & $\begin{array}{l}26.10 \\
1 * *\end{array}$ & $\begin{array}{l}10.05 \\
1 *\end{array}$ \\
\hline 12 & $\begin{array}{l}\mathrm{ICPH} \\
4683\end{array}$ & $\begin{array}{l}- \\
9.333 \\
*\end{array}$ & $\begin{array}{l}- \\
3.774 \\
*\end{array}$ & $\begin{array}{l}-\overline{12.82} \\
*\end{array}$ & $\begin{array}{l} \\
1.94 \\
8\end{array}$ & $\begin{array}{l}- \\
1.94 \\
8\end{array}$ & $\begin{array}{l}- \\
10.1 \\
2 *\end{array}$ & $\begin{array}{l}26.49 \\
6^{* *}\end{array}$ & $\begin{array}{l}17.46 \\
* *\end{array}$ & $\begin{array}{l}15.64 \\
3 * *\end{array}$ & $\begin{array}{l}24.35 \\
4 * *\end{array}$ & $\begin{array}{l}22.67 \\
6^{* *}\end{array}$ & $\begin{array}{l}5.659 \\
*\end{array}$ \\
\hline 13 & $\begin{array}{l}\mathrm{ICPH} \\
4682\end{array}$ & $\begin{array}{l}- \\
7.547 \\
*\end{array}$ & $\begin{array}{l}- \\
7.547 \\
*\end{array}$ & $\begin{array}{l}- \\
16.24 \\
* *\end{array}$ & $\begin{array}{l}- \\
2.59 \\
7\end{array}$ & $\begin{array}{l}- \\
2.59 \\
7 *\end{array}$ & $\begin{array}{l}- \\
10.7 \\
1 *\end{array}$ & $\begin{array}{l}7.488 \\
*\end{array}$ & 1.328 & $\begin{array}{l}- \\
3.422 \\
*\end{array}$ & $\begin{array}{l}6.413 \\
*\end{array}$ & 0.969 & $\begin{array}{l}- \\
3.127 \\
*\end{array}$ \\
\hline 14 & $\begin{array}{l}\text { ICPH } \\
4567\end{array}$ & $\begin{array}{l}- \\
10.11 \\
*\end{array}$ & $\begin{array}{l}- \\
6.289 \\
*\end{array}$ & $\begin{array}{l}- \\
15.09 \\
9 *\end{array}$ & $\begin{array}{l} \\
2.09 \\
*\end{array}$ & $\begin{array}{l}- \\
3.67 \\
9^{*}\end{array}$ & $\begin{array}{l}- \\
11.7 \\
1 *\end{array}$ & $\begin{array}{l}11.19 \\
6^{*}\end{array}$ & $\begin{array}{l}2.516 \\
*\end{array}$ & 2.516 & $\begin{array}{l}20.61 \\
2 * *\end{array}$ & $\begin{array}{l}10.79 \\
3^{*}\end{array}$ & $\begin{array}{l}13.98 \\
2^{*}\end{array}$ \\
\hline
\end{tabular}

Where, $*, * *=$ significant at $5 \%$ and $1 \%$ level of significance, respectively. 
Note: MPH-mid parent heterosis, BPH-better parent heterosis, SCH-Standard check heterosis (Asha).

Note: DF-Days to $50 \%$ flowering, DM-Days to maturity, NPBr- No.of primary branches plant ${ }^{-1}$ and NSc.Br-No.of secondary branches plant ${ }^{-1}$.

Table 1b:- Mid parent (MPH), better parent (BPH) and standard heterosis (SH) for yield and yield components in

\begin{tabular}{|c|c|c|c|c|c|c|c|c|c|c|c|c|c|}
\hline & & & Pht & & & $\mathbf{P} / \mathbf{P I}$ & & & $\mathbf{S} / \mathbf{P}$ & & & $\mathbf{S} / \mathbf{P I}$ & \\
\hline $\begin{array}{l}\text { Sl. } \\
\text { No. }\end{array}$ & $\begin{array}{l}\text { Hybri } \\
\text { d }\end{array}$ & $\begin{array}{l}\text { MP } \\
\text { H }\end{array}$ & BPH & SCH & МРH & ВPH & SCH & $\begin{array}{l}\text { MP } \\
\text { H }\end{array}$ & $\begin{array}{l}\text { BP } \\
\text { H }\end{array}$ & $\begin{array}{l}\text { SC } \\
\text { H }\end{array}$ & МРН & BPH & SCH \\
\hline 1 & $\begin{array}{l}\text { ICPH } \\
4746\end{array}$ & $\begin{array}{l}6.74 \\
7 *\end{array}$ & $\begin{array}{l}5.348 \\
*\end{array}$ & $\begin{array}{l}8.771 \\
*\end{array}$ & $\begin{array}{l}17.76 \\
4 * *\end{array}$ & -0.278 & $\begin{array}{l}43.06 \\
2 * *\end{array}$ & $\begin{array}{l}2.57 \\
9\end{array}$ & $\begin{array}{l}2.43 \\
4\end{array}$ & $\begin{array}{l}4.48 \\
9 *\end{array}$ & $\begin{array}{l}5.564 \\
*\end{array}$ & $\begin{array}{l}- \\
10.90 \\
*\end{array}$ & $\begin{array}{l}22.52 \\
1 * *\end{array}$ \\
\hline 2 & $\begin{array}{l}\text { ICPH } \\
4571\end{array}$ & $\begin{array}{l}6.29 \\
9^{*}\end{array}$ & $\begin{array}{l}5.088 \\
*\end{array}$ & $\begin{array}{l}8.121 \\
*\end{array}$ & $\begin{array}{l}48.79 \\
8^{* *}\end{array}$ & $\begin{array}{l}17.62 \\
1 * *\end{array}$ & $\begin{array}{l}101.4 \\
55^{* * *}\end{array}$ & $\begin{array}{l}2.62 \\
2 *\end{array}$ & $\begin{array}{l}2.62 \\
2^{*}\end{array}$ & $\begin{array}{l}4.68 \\
*\end{array}$ & $\begin{array}{l}13.98 \\
5 * *\end{array}$ & $\begin{array}{l}- \\
7.043 \\
*\end{array}$ & $\begin{array}{l}39.37 \\
8 * *\end{array}$ \\
\hline 3 & $\begin{array}{l}\text { ICPH } \\
4748\end{array}$ & $\begin{array}{l}- \\
7.70 \\
4 *\end{array}$ & $\begin{array}{l}- \\
15.88 \\
7 * *\end{array}$ & $\begin{array}{l}7.038 \\
*\end{array}$ & $\begin{array}{l}45.29 \\
1 * *\end{array}$ & $\begin{array}{l}23.98 \\
2 * *\end{array}$ & $\begin{array}{l}75.29 \\
7 * *\end{array}$ & $\begin{array}{l}- \\
1.83 \\
4\end{array}$ & $\begin{array}{l}- \\
5.17 \\
7 *\end{array}$ & $\begin{array}{l}- \\
0.28 \\
7\end{array}$ & $\begin{array}{l}26.26 \\
1 * *\end{array}$ & $\begin{array}{l}19.26 \\
1 * *\end{array}$ & $\begin{array}{l}49.74 \\
* *\end{array}$ \\
\hline 4 & $\begin{array}{l}\text { ICPH } \\
4606\end{array}$ & $\begin{array}{l}- \\
7.87 \\
9 *\end{array}$ & $\begin{array}{l}- \\
19.57 \\
4 * *\end{array}$ & 2.345 & $\begin{array}{l}- \\
3.676 \\
*\end{array}$ & $\begin{array}{l}- \\
6.290 \\
*\end{array}$ & $\begin{array}{l}40.09 \\
8^{* *}\end{array}$ & $\begin{array}{l}1.11 \\
1\end{array}$ & $\begin{array}{l}- \\
0.81 \\
7\end{array}$ & $\begin{array}{l}4.29 \\
8^{*}\end{array}$ & $\begin{array}{l}- \\
6.448 \\
*\end{array}$ & $\begin{array}{l}- \\
15.36 \\
6 * *\end{array}$ & $\begin{array}{l}16.73 \\
7 * *\end{array}$ \\
\hline 5 & $\begin{array}{l}\text { ICPH } \\
4573\end{array}$ & $\begin{array}{l}- \\
5.32 \\
9^{*} \\
\end{array}$ & $\begin{array}{l}- \\
13.05 \\
*\end{array}$ & $\begin{array}{l}10.64 \\
8^{*}\end{array}$ & $\begin{array}{l}8.906 \\
*\end{array}$ & $\begin{array}{l}6.675 \\
*\end{array}$ & $\begin{array}{l}50.82 \\
7 * *\end{array}$ & $\begin{array}{l}- \\
2.01 \\
5\end{array}$ & $\begin{array}{l}- \\
2.81 \\
6^{*}\end{array}$ & $\begin{array}{l}2.19 \\
7\end{array}$ & $\begin{array}{l}7.558 \\
*\end{array}$ & 0.511 & $\begin{array}{l}29.12 \\
5 * *\end{array}$ \\
\hline 6 & $\begin{array}{l}\text { ICPH } \\
4588\end{array}$ & $\begin{array}{l} \\
2.58 \\
8 \\
\end{array}$ & $\begin{array}{l}- \\
11.91 \\
5^{*}\end{array}$ & $\begin{array}{l}12.09 \\
2 * *\end{array}$ & $\begin{array}{l}- \\
10.85 \\
*\end{array}$ & $\begin{array}{l}- \\
18.62 \\
8 * *\end{array}$ & $\begin{array}{l}39.37 \\
* *\end{array}$ & $\begin{array}{l}- \\
3.36 \\
6^{*} \\
\end{array}$ & $\begin{array}{l}- \\
4.81 \\
4 *\end{array}$ & $\begin{array}{l}0.09 \\
6\end{array}$ & $\begin{array}{l}7.342 \\
*\end{array}$ & $\begin{array}{l}- \\
6.369 \\
*\end{array}$ & $\begin{array}{l}40.38 \\
9 * *\end{array}$ \\
\hline 7 & $\begin{array}{l}\text { ICPH } \\
4679\end{array}$ & $\begin{array}{l}7.38 \\
4^{*}\end{array}$ & $\begin{array}{l}6.736 \\
*\end{array}$ & $\begin{array}{l}11.55 \\
*\end{array}$ & $\begin{array}{l}14.62 \\
4 * *\end{array}$ & $\begin{array}{l}- \\
6.740 \\
*\end{array}$ & $\begin{array}{l}33.79 \\
* *\end{array}$ & $\begin{array}{l}3.93 \\
3 *\end{array}$ & $\begin{array}{l}3.64 \\
1 *\end{array}$ & $\begin{array}{l}6.01 \\
7^{*}\end{array}$ & $\begin{array}{l}11.21 \\
5^{*}\end{array}$ & -1.358 & $\begin{array}{l}35.64 \\
1 * *\end{array}$ \\
\hline 8 & $\begin{array}{l}\text { ICPH } \\
4680\end{array}$ & $\begin{array}{l}1.70 \\
9\end{array}$ & 1.796 & $\begin{array}{l}6.388 \\
*\end{array}$ & $\begin{array}{l}29.34 \\
7 * *\end{array}$ & $\begin{array}{l}22.91 \\
7 * *\end{array}$ & $\begin{array}{l}22.81 \\
4 * *\end{array}$ & $\begin{array}{l}- \\
0.81 \\
1 \\
\end{array}$ & $\begin{array}{l}- \\
2.89 \\
4^{*}\end{array}$ & $\begin{array}{l}- \\
0.66 \\
9\end{array}$ & $5.36^{*}$ & $\begin{array}{l}- \\
2.671 \\
*\end{array}$ & $\begin{array}{l}22.20 \\
3 * *\end{array}$ \\
\hline 9 & $\begin{array}{l}\mathrm{ICPH} \\
4602\end{array}$ & $\begin{array}{l}2.98 \\
7^{*}\end{array}$ & -1.727 & 2.706 & $\begin{array}{l}12.35 \\
4 * *\end{array}$ & $\begin{array}{l}- \\
10.01 \\
1 *\end{array}$ & $\begin{array}{l}34.53 \\
5 * *\end{array}$ & $\begin{array}{l}- \\
1.59 \\
6\end{array}$ & $\begin{array}{l} \\
2.14 \\
8\end{array}$ & $\begin{array}{l}0.09 \\
6\end{array}$ & $\begin{array}{l}7.241 \\
*\end{array}$ & $\begin{array}{l}- \\
5.011 \\
*\end{array}$ & $\begin{array}{l}31.02 \\
* *\end{array}$ \\
\hline 10 & $\begin{array}{l}\mathrm{ICPH} \\
4572\end{array}$ & $\begin{array}{l}7.95 \\
5^{*}\end{array}$ & $\begin{array}{l}6.947 \\
*\end{array}$ & $\begin{array}{l}13.89 \\
7 * *\end{array}$ & $\begin{array}{l}13.04 \\
3 * *\end{array}$ & $\begin{array}{l}- \\
5.971 \\
*\end{array}$ & $\begin{array}{l}27.49 \\
9 * *\end{array}$ & $\begin{array}{l}0.83 \\
6\end{array}$ & $\begin{array}{l}0.27 \\
7\end{array}$ & $\begin{array}{l}3.72 \\
5^{*}\end{array}$ & $\begin{array}{l}9.433 \\
*\end{array}$ & 0.040 & $\begin{array}{l}28.52 \\
1 * *\end{array}$ \\
\hline 11 & $\begin{array}{l}\text { ICPH } \\
4564\end{array}$ & $\begin{array}{l}10.1 \\
83^{*}\end{array}$ & $\begin{array}{l}9.326 \\
*\end{array}$ & $\begin{array}{l}14.25 \\
8 * *\end{array}$ & $\begin{array}{l}13.34 \\
6 * *\end{array}$ & $\begin{array}{l}- \\
13.55 \\
3 * *\end{array}$ & $\begin{array}{l}48.06 \\
2 * *\end{array}$ & $\begin{array}{l}- \\
0.32 \\
7\end{array}$ & $\begin{array}{l}- \\
0.46 \\
7\end{array}$ & $\begin{array}{l}1.81 \\
5\end{array}$ & $\begin{array}{l}13.94 \\
5 * *\end{array}$ & -2.592 & $\begin{array}{l}46.05 \\
2 * *\end{array}$ \\
\hline 12 & $\begin{array}{l}\text { ICPH } \\
4683\end{array}$ & $\begin{array}{l}3.83 \\
5^{*}\end{array}$ & $\begin{array}{l}2.760 \\
*\end{array}$ & $\begin{array}{l}7.579 \\
*\end{array}$ & $\begin{array}{l}22.59 \\
3^{* *}\end{array}$ & -1.748 & $\begin{array}{l}62.83 \\
* *\end{array}$ & $\begin{array}{l}1.37 \\
9\end{array}$ & $\begin{array}{l}- \\
1.02 \\
1 \\
\end{array}$ & $\begin{array}{l}1.81 \\
5\end{array}$ & $\begin{array}{l}22.24 \\
* *\end{array}$ & $\begin{array}{l}23.61 \\
5 * *\end{array}$ & $\begin{array}{l}55.20 \\
7 * *\end{array}$ \\
\hline 13 & $\begin{array}{l}\text { ICPH } \\
4682\end{array}$ & $\begin{array}{l}- \\
2.63 \\
2^{*}\end{array}$ & $\begin{array}{l}-974 \\
* \\
\end{array}$ & 0.179 & $\begin{array}{l}3.175 \\
*\end{array}$ & $\begin{array}{l}- \\
3.756 \\
*\end{array}$ & $\begin{array}{l}59.50 \\
2 * *\end{array}$ & $\begin{array}{l}- \\
1.58 \\
7\end{array}$ & $\begin{array}{l} \\
2.13 \\
6\end{array}$ & $\begin{array}{l}0.66 \\
9\end{array}$ & $\begin{array}{l}11.95 \\
2^{*}\end{array}$ & $\begin{array}{l}8.237 \\
*\end{array}$ & $\begin{array}{l}48.83 \\
5^{* *}\end{array}$ \\
\hline 14 & $\begin{array}{l}\text { ICPH } \\
4567\end{array}$ & $\begin{array}{l}2.46 \\
1\end{array}$ & 2.281 & $\begin{array}{l}5.233 \\
*\end{array}$ & $\begin{array}{l}26.41 \\
6^{* *}\end{array}$ & $\begin{array}{l}24.36 \\
9 * *\end{array}$ & $\begin{array}{l}113.0 \\
11 * *\end{array}$ & $\begin{array}{l}- \\
0.04 \\
7 \\
\end{array}$ & $\begin{array}{l}- \\
0.46 \\
4\end{array}$ & $\begin{array}{l}2.38 \\
8^{*}\end{array}$ & $\begin{array}{l}44.12 \\
9 * *\end{array}$ & $\begin{array}{l}33.76 \\
9 * *\end{array}$ & $\begin{array}{l}100.5 \\
7 * *\end{array}$ \\
\hline
\end{tabular}

Where, $* * *=$ significant at $5 \%$ and $1 \%$ level of significance, respectivelyNote: MPH-mid parent heterosis, $\mathrm{BPH}$-better parent heterosis, SCH-Standard check heterosis (Asha).

Note: Pht-Plant height, P/Pl-Pods plant ${ }^{-1}$, S/P-Seeds pod $^{-1}$ and S/Pl-Seeds plant ${ }^{-1}$. 
Table 1c:- Mid parent (MPH), better parent (BPH) and standard heterosis (SH) for yield and yield components in pigeonpea hybrids (conti..)

\begin{tabular}{|c|c|c|c|c|c|c|c|c|c|c|c|c|c|}
\hline & & & $\begin{array}{l}\text { 100sw } \\
\text { t. }\end{array}$ & & & BY/PI & & & Y/PI & & & PF\% & \\
\hline $\begin{array}{l}\text { Sl. } \\
\text { No }\end{array}$ & $\begin{array}{l}\text { Hybri } \\
\text { d }\end{array}$ & $\begin{array}{l}\text { MP } \\
\text { H }\end{array}$ & ВPH & SCH & $\begin{array}{l}\text { MP } \\
\text { H }\end{array}$ & ВPH & SCH & MPH & BPH & SCH & MPH & BPH & SCH \\
\hline 1 & $\begin{array}{l}\text { ICPH } \\
4746\end{array}$ & $\begin{array}{l}2.51 \\
*\end{array}$ & $-3.64 *$ & $8.33 *$ & $\overline{0}-46$ & $-3.60 *$ & $\begin{array}{l}- \\
10.20 \\
*\end{array}$ & $4.26^{*}$ & $\begin{array}{l}- \\
24.73 \\
* *\end{array}$ & $\begin{array}{l}- \\
9.90 \\
1 *\end{array}$ & 0.784 & $-\overline{0}-388$ & $\begin{array}{l}- \\
1.90 \\
5\end{array}$ \\
\hline 2 & $\begin{array}{l}\text { ICPH } \\
4571\end{array}$ & $\begin{array}{l}4.98 \\
*\end{array}$ & $4.51^{*}$ & $\begin{array}{l}- \\
12.50 \\
* *\end{array}$ & $\begin{array}{l}25.2 \\
5^{* *}\end{array}$ & $\begin{array}{l}16.28 * \\
*\end{array}$ & $\begin{array}{l}18.45 \\
* *\end{array}$ & $\begin{array}{l}- \\
26.02 \\
* *\end{array}$ & $\begin{array}{l}- \\
55.88 \\
* *\end{array}$ & $\begin{array}{l}21.6 \\
76^{* * *}\end{array}$ & $\overline{-}-0.068$ & $-\overline{0}-265$ & $\begin{array}{l}-\overline{4} \\
4.06 \\
8^{*}\end{array}$ \\
\hline 3 & $\begin{array}{l}\text { ICPH } \\
4748\end{array}$ & $\begin{array}{l}- \\
0.19\end{array}$ & $-8.15^{*}$ & $-\overline{4.02 *}$ & $\begin{array}{l}56.4 \\
0 * *\end{array}$ & $\begin{array}{l}34.54 * \\
*\end{array}$ & $\begin{array}{l}20.02 \\
* *\end{array}$ & $\begin{array}{l}37.61 \\
* *\end{array}$ & 1.20 & $\begin{array}{l}- \\
8.41 \\
4 *\end{array}$ & $\begin{array}{l}- \\
9.239 \\
*\end{array}$ & $\begin{array}{l}- \\
10.49 \\
3 *\end{array}$ & $\begin{array}{l}- \\
1.26 \\
9\end{array}$ \\
\hline 4 & $\begin{array}{l}\text { ICPH } \\
4606\end{array}$ & $\begin{array}{l}-\overline{4} \\
4.71 \\
*\end{array}$ & $\begin{array}{l}- \\
10.00 \\
*\end{array}$ & $-\overline{5.96 *}$ & $\begin{array}{l}16.2 \\
9 * *\end{array}$ & $-6.47 *$ & -1.21 & $\begin{array}{l}51.71 \\
* *\end{array}$ & $6.78^{*}$ & $\begin{array}{l}11.6 \\
24^{*}\end{array}$ & $\begin{array}{l}- \\
7.995 \\
*\end{array}$ & $\begin{array}{l}-\overline{8} \\
8.156 \\
*\end{array}$ & $\begin{array}{l}- \\
1.14 \\
1\end{array}$ \\
\hline 5 & $\begin{array}{l}\text { ICPH } \\
4573\end{array}$ & $\begin{array}{l}- \\
3.39 \\
*\end{array}$ & $-6.12^{*}$ & -1.90 & $\begin{array}{l}36.8 \\
5 * *\end{array}$ & $8.21 *$ & $\begin{array}{l}19.60 \\
* *\end{array}$ & $\begin{array}{l}86.08 \\
* *\end{array}$ & $\begin{array}{l}38.85 \\
* *\end{array}$ & $\begin{array}{l}20.1 \\
66^{* *}\end{array}$ & $\begin{array}{l}- \\
7.089 \\
*\end{array}$ & $\begin{array}{l}- \\
10.56 \\
1 *\end{array}$ & $\begin{array}{l}- \\
4.06 \\
8^{*}\end{array}$ \\
\hline 6 & $\begin{array}{l}\text { ICPH } \\
4588\end{array}$ & $\begin{array}{l}- \\
5.59 \\
*\end{array}$ & $\begin{array}{l}- \\
15.31 \\
* *\end{array}$ & $\begin{array}{l}- \\
11.51 \\
* *\end{array}$ & $\begin{array}{l}26.8 \\
4 * *\end{array}$ & $3.43^{*}$ & $5.37 *$ & $\begin{array}{l}19.67 \\
* *\end{array}$ & $\begin{array}{l}- \\
20.87 \\
* *\end{array}$ & $\begin{array}{l}4.56 \\
4^{*}\end{array}$ & $\begin{array}{l}- \\
3.387 \\
*\end{array}$ & $\begin{array}{l}- \\
8.544 \\
*\end{array}$ & $\begin{array}{l}- \\
1.90 \\
5\end{array}$ \\
\hline 7 & $\begin{array}{l}\text { ICPH } \\
4679\end{array}$ & $\begin{array}{l}2.55 \\
*\end{array}$ & -1.28 & $\begin{array}{l} \\
6.08 *\end{array}$ & $\begin{array}{l}12.4 \\
2 * *\end{array}$ & $5.20 *$ & $\begin{array}{l}12.45 \\
* *\end{array}$ & $\begin{array}{l}10.98 \\
*\end{array}$ & $\begin{array}{l}- \\
21.97 \\
* *\end{array}$ & $\begin{array}{l}- \\
6.59 \\
1 *\end{array}$ & $\begin{array}{l} \\
0.321\end{array}$ & $\begin{array}{l}- \\
0.894\end{array}$ & $\begin{array}{l}- \\
1.26 \\
9\end{array}$ \\
\hline 8 & $\begin{array}{l}\text { ICPH } \\
4680\end{array}$ & 1.91 & 1.81 & $\begin{array}{l}- \\
10.38 \\
*\end{array}$ & $\begin{array}{l}27.7 \\
1 * *\end{array}$ & $\begin{array}{l}17.15 * \\
*\end{array}$ & $\begin{array}{l}25.22 \\
* *\end{array}$ & $\begin{array}{l}16.68 \\
* *\end{array}$ & $\begin{array}{l}- \\
10.31 \\
*\end{array}$ & $\begin{array}{l}- \\
18.8 \\
3 * *\end{array}$ & $\begin{array}{l}- \\
5.210 \\
*\end{array}$ & $\begin{array}{l}- \\
9.801 \\
*\end{array}$ & $\begin{array}{l}- \\
0.50 \\
5\end{array}$ \\
\hline 9 & $\begin{array}{l}\text { ICPH } \\
4602\end{array}$ & 2.17 & -0.50 & $7.58 *$ & $\overline{0}-8.84$ & -1.42 & $5.37 *$ & $\begin{array}{l}39.96 \\
* *\end{array}$ & 2.54 & $\begin{array}{l}7.19 \\
22 *\end{array}$ & $\begin{array}{l}- \\
3.867 \\
*\end{array}$ & $\begin{array}{l}- \\
7.447 \\
*\end{array}$ & $\begin{array}{l}-\overline{0} \\
0.37 \\
8\end{array}$ \\
\hline 10 & $\begin{array}{l}\text { ICPH } \\
4572\end{array}$ & $\overline{-}-82$ & $-6.14^{*}$ & $-\overline{7.45 *}$ & $\begin{array}{l}- \\
0.19\end{array}$ & -1.83 & $8.50^{*}$ & $\begin{array}{l}55.17 \\
* *\end{array}$ & $\begin{array}{l}21.19 \\
* *\end{array}$ & $\begin{array}{l}4.87 \\
7 *\end{array}$ & $\begin{array}{l}- \\
4.289 \\
*\end{array}$ & $-\overline{4.47 *}$ & $\begin{array}{l}4.83 \\
1 *\end{array}$ \\
\hline 11 & $\begin{array}{l}\text { ICPH } \\
4564\end{array}$ & 0.22 & $-2.66^{*}$ & $\begin{array}{l}- \\
14.31 \\
* *\end{array}$ & $\begin{array}{l}7.65 \\
*\end{array}$ & $5.12^{*}$ & $\begin{array}{l}12.36 \\
* *\end{array}$ & $\begin{array}{l}- \\
23.27 \\
* *\end{array}$ & $\begin{array}{l}- \\
54.87 \\
* *\end{array}$ & $\begin{array}{l}24.4 \\
7 * *\end{array}$ & 0.779 & $-\overline{1.149}$ & $\begin{array}{l}- \\
1.52 \\
3\end{array}$ \\
\hline 12 & $\begin{array}{l}\text { ICPH } \\
4683\end{array}$ & 0.63 & -1.24 & $\begin{array}{l} \\
13.25 \\
* *\end{array}$ & $\begin{array}{l}47.7 \\
9 * *\end{array}$ & $\begin{array}{l}44.77 * \\
*\end{array}$ & $\begin{array}{l}29.15 \\
* *\end{array}$ & $\begin{array}{l}41.11 \\
* *\end{array}$ & $\begin{array}{l}32.12 \\
* *\end{array}$ & $\begin{array}{l}37.0 \\
22 * *\end{array}$ & $\begin{array}{l}- \\
5.744 \\
*\end{array}$ & $\begin{array}{l}- \\
10.14 \\
7 *\end{array}$ & $\begin{array}{l}- \\
0.88 \\
7\end{array}$ \\
\hline 13 & $\begin{array}{l}\text { ICPH } \\
4682\end{array}$ & $\begin{array}{l}- \\
5.81 \\
*\end{array}$ & $\begin{array}{l} \\
11.05 \\
*\end{array}$ & $\begin{array}{l}- \\
15.37 \\
* *\end{array}$ & $\begin{array}{l}9.20 \\
*\end{array}$ & $4.75^{*}$ & -2.42 & $\begin{array}{l} \\
7.12 *\end{array}$ & $\begin{array}{l}- \\
13.33 \\
* *\end{array}$ & $\begin{array}{l}3.75 \\
*\end{array}$ & $\begin{array}{l}- \\
3.844 \\
*\end{array}$ & $\begin{array}{l}- \\
4.577 \\
*\end{array}$ & $\begin{array}{l}- \\
4.57 \\
7 *\end{array}$ \\
\hline 14 & $\begin{array}{l}\text { ICPH } \\
4567\end{array}$ & $\overline{-}-\overline{1.66}$ & -2.58 & $\begin{array}{l}- \\
17.62 \\
* *\end{array}$ & $\begin{array}{l}46.8 \\
0 * *\end{array}$ & $\begin{array}{l}35.06^{*} \\
*\end{array}$ & $\begin{array}{l}37.58 \\
* *\end{array}$ & $\begin{array}{l}- \\
27.03 \\
* *\end{array}$ & $\begin{array}{l}- \\
49.80 \\
* *\end{array}$ & $\begin{array}{l}38.4 \\
56 * *\end{array}$ & $\begin{array}{l}- \\
2.664 \\
*\end{array}$ & $\begin{array}{l}- \\
4.704 \\
*\end{array}$ & $\begin{array}{l}- \\
4.70 \\
4 *\end{array}$ \\
\hline
\end{tabular}

Where, $*, * *=$ significant at $5 \%$ and $1 \%$ level of significance $\quad$ where, $*, * *=$ significant at $5 \%$ and $1 \%$ level of significance, respectively, respectivelyNote: $\mathrm{MPH}-$ mid parent heterosis, BPH-better parent heterosis, $\mathrm{SCH}-$ Standard check heterosis (Asha) Note: PF\%-Pollen fertility, 100Swt-100-Seed weight, BY/PI-Biological yield plant ${ }^{-1}$ and Y/Pl-Yield plant ${ }^{-1}$ 
Table 1d:- Mid parent (MPH), better parent (BPH) and standard heterosis $(\mathrm{SH})$ for yield and yield components in pigeonpea hybrids (cont.)

\begin{tabular}{|c|c|c|c|c|c|c|c|c|c|c|c|c|c|}
\hline & & & $\begin{array}{l}\mathbf{Y}(\mathbf{k g} / \\
\text { ha) }\end{array}$ & & & HI & & & $\begin{array}{l}\text { DR } \\
\%\end{array}$ & & & SPC & \\
\hline $\begin{array}{l}\text { Sl. } \\
\text { No. }\end{array}$ & Hybrid & MPH & BPH & SCH & $\begin{array}{l}\text { MP } \\
\mathbf{H} \\
\end{array}$ & BPH & SCH & $\begin{array}{l}\text { MP } \\
\text { H }\end{array}$ & $\begin{array}{l}\text { BP } \\
\text { H }\end{array}$ & SCH & $\begin{array}{l}\text { MP } \\
\text { H }\end{array}$ & BPH & SCH \\
\hline 1 & $\begin{array}{l}\text { ICPH } \\
4746\end{array}$ & $\begin{array}{l}54.74 \\
* *\end{array}$ & $\begin{array}{l}13.90 \\
*\end{array}$ & $\begin{array}{l}47.41 \\
* *\end{array}$ & -3.33 & $\begin{array}{l}- \\
20.18 \\
* *\end{array}$ & -0.88 & $\begin{array}{l}7.56 \\
1^{*}\end{array}$ & $\begin{array}{l}5.80 \\
*\end{array}$ & $\begin{array}{l}- \\
3.31 \\
*\end{array}$ & $\begin{array}{l}- \\
0.19 \\
8\end{array}$ & -0.76 & $\begin{array}{l}- \\
3.85 \\
*\end{array}$ \\
\hline 2 & $\begin{array}{l}\text { ICPH } \\
4571\end{array}$ & $\begin{array}{l}73.18 \\
* *\end{array}$ & $\begin{array}{l}40.72 \\
* *\end{array}$ & $\begin{array}{l}37.55 \\
* *\end{array}$ & $\begin{array}{l}- \\
16.95 \\
*\end{array}$ & $\begin{array}{l}- \\
26.66 \\
* *\end{array}$ & $\begin{array}{l}- \\
22.58 \\
* *\end{array}$ & $\begin{array}{l}5.10 \\
5^{*}\end{array}$ & $\begin{array}{l}-\bar{l} \\
0.10\end{array}$ & $\begin{array}{l}-1.99 \\
\end{array}$ & $\begin{array}{l}0.63 \\
3\end{array}$ & 0.61 & -3.62 \\
\hline 3 & $\begin{array}{l}\text { ICPH } \\
4748\end{array}$ & $\begin{array}{l}60.32 \\
* *\end{array}$ & $\begin{array}{l}15.44 \\
*\end{array}$ & $\begin{array}{l}12.30 \\
*\end{array}$ & -3.89 & $\begin{array}{l} \\
9.04 *\end{array}$ & 1.10 & $\begin{array}{l}2.73 \\
1 *\end{array}$ & $\begin{array}{l}2.10 \\
*\end{array}$ & -1.04 & $\begin{array}{l}0.80 \\
7\end{array}$ & -2.22 & -1.99 \\
\hline 4 & $\begin{array}{l}\text { ICPH } \\
4606\end{array}$ & $\begin{array}{l}79.93 \\
* *\end{array}$ & $\begin{array}{l}38.21 \\
* *\end{array}$ & $\begin{array}{l}10.36 \\
*\end{array}$ & $\begin{array}{l}22.85 \\
*\end{array}$ & $\begin{array}{l}10.54 \\
*\end{array}$ & $\begin{array}{l}22.87 \\
* *\end{array}$ & $\begin{array}{l}2.99 \\
4^{*}\end{array}$ & 0.83 & $\begin{array}{l}- \\
2.27 \\
*\end{array}$ & $\begin{array}{l}- \\
5.77 \\
8^{*}\end{array}$ & $\begin{array}{l}- \\
8.39 \\
*\end{array}$ & $\begin{array}{l}- \\
8.18 \\
*\end{array}$ \\
\hline 5 & $\begin{array}{l}\text { ICPH } \\
4573\end{array}$ & $\begin{array}{l}115.7 \\
3 * *\end{array}$ & $\begin{array}{l}57.78 \\
* *\end{array}$ & $\begin{array}{l}46.01 \\
* *\end{array}$ & 4.02 & $\begin{array}{l}- \\
6.50 *\end{array}$ & $3.93 *$ & $\begin{array}{l}- \\
3.22 \\
3^{*}\end{array}$ & $\begin{array}{l}- \\
7.34 \\
*\end{array}$ & $\begin{array}{l}- \\
10.2 \\
*\end{array}$ & $\begin{array}{l}3.49 \\
3^{*}\end{array}$ & -0.71 & -0.48 \\
\hline 6 & $\begin{array}{l}\mathrm{ICPH} \\
4588\end{array}$ & $\begin{array}{l}96.31 \\
* *\end{array}$ & $\begin{array}{l}41.15 \\
* *\end{array}$ & $\begin{array}{l}37.97 \\
* *\end{array}$ & $9.28^{*}$ & $6.53 *$ & $\begin{array}{l}18.41 \\
*\end{array}$ & $\begin{array}{l}- \\
0.46 \\
4\end{array}$ & $\begin{array}{l}-\overline{1} \\
1.06\end{array}$ & $\begin{array}{l}- \\
2.93 \\
*\end{array}$ & $\begin{array}{l}8.62 \\
4^{*}\end{array}$ & $\begin{array}{l}- \\
10.6 \\
6^{*}\end{array}$ & $\begin{array}{l}- \\
10.4 \\
6^{*}\end{array}$ \\
\hline 7 & $\begin{array}{l}\text { ICPH } \\
4679\end{array}$ & $\begin{array}{l}51.08 \\
* *\end{array}$ & $5.12^{*}$ & $\begin{array}{l}36.05 \\
* *\end{array}$ & $\begin{array}{l} \\
16.04 \\
*\end{array}$ & $\begin{array}{l}- \\
30.42 \\
* *\end{array}$ & $\begin{array}{l}- \\
13.59 \\
*\end{array}$ & $\begin{array}{l}- \\
2.67 \\
5^{*}\end{array}$ & $\begin{array}{l}- \\
3.46 \\
*\end{array}$ & $\begin{array}{l}- \\
10.3 \\
3^{*}\end{array}$ & $\begin{array}{l}0.67 \\
9\end{array}$ & -1.27 & $\begin{array}{l}- \\
4.35 \\
*\end{array}$ \\
\hline 8 & $\begin{array}{l}\text { ICPH } \\
4680\end{array}$ & $\begin{array}{l}54.96 \\
* *\end{array}$ & $\begin{array}{l}17.84 \\
*\end{array}$ & $\begin{array}{l}14.64 \\
*\end{array}$ & $\begin{array}{l}15.07 \\
*\end{array}$ & $4.89^{*}$ & $4.07 *$ & $\begin{array}{l}3.02 \\
0^{*}\end{array}$ & 1.49 & -2.84 & $\begin{array}{l}1.59 \\
5\end{array}$ & 1.01 & $\begin{array}{l}- \\
4.83 \\
*\end{array}$ \\
\hline 9 & $\begin{array}{l}\text { ICPH } \\
4602\end{array}$ & $\begin{array}{l}51.35 \\
* *\end{array}$ & $\begin{array}{l}23.71 \\
*\end{array}$ & -1.23 & $\begin{array}{l}19.43 \\
* *\end{array}$ & $\begin{array}{l}14.58 \\
*\end{array}$ & 1.84 & $\begin{array}{l}- \\
1.40 \\
1 *\end{array}$ & $\begin{array}{l}- \\
1.42\end{array}$ & $\begin{array}{l}8.43 \\
*\end{array}$ & $\begin{array}{l}- \\
1.45 \\
6\end{array}$ & -2.26 & $\begin{array}{l}- \\
7.47 \\
*\end{array}$ \\
\hline 10 & $\begin{array}{l}\text { ICPH } \\
4572\end{array}$ & $\begin{array}{l}57.36 \\
* *\end{array}$ & $\begin{array}{l}21.77 \\
*\end{array}$ & $\begin{array}{l}12.69 \\
* \quad\end{array}$ & -3.24 & $\begin{array}{l}- \\
7.07 *\end{array}$ & $\begin{array}{l}- \\
17.59 \\
*\end{array}$ & $\begin{array}{l}2.74 \\
1 *\end{array}$ & 0.41 & $\begin{array}{l}- \\
6.73 \\
*\end{array}$ & $\begin{array}{l}- \\
1.93 \\
7\end{array}$ & -2.48 & $\begin{array}{l}- \\
9.18 \\
*\end{array}$ \\
\hline 11 & $\begin{array}{l}\text { ICPH } \\
4564\end{array}$ & $\begin{array}{l}122.9 \\
9 * *\end{array}$ & $\begin{array}{l}69.31 \\
* *\end{array}$ & $\begin{array}{l}65.49 \\
* *\end{array}$ & $\begin{array}{l}57.76 \\
* *\end{array}$ & $\begin{array}{l}39.91 \\
* *\end{array}$ & $\begin{array}{l}47.68 \\
* *\end{array}$ & $\begin{array}{l}5.80 \\
9 *\end{array}$ & $\begin{array}{l}3.00 \\
*\end{array}$ & 1.05 & $\begin{array}{l}3.06 \\
8^{*}\end{array}$ & 1.66 & $\begin{array}{l}- \\
2.66 \\
*\end{array}$ \\
\hline 12 & $\begin{array}{l}\mathrm{ICPH} \\
4683\end{array}$ & $\begin{array}{l}21.28 \\
*\end{array}$ & 9.77* & $6.79 *$ & $7.18^{*}$ & $2.75^{*}$ & 1.95 & $\begin{array}{l}3.28 \\
8^{*}\end{array}$ & 1.09 & -3.22 & $\begin{array}{l}6.23 \\
0^{*}\end{array}$ & $\begin{array}{l}5.95 \\
*\end{array}$ & -0.18 \\
\hline 13 & $\begin{array}{l}\text { ICPH } \\
4682\end{array}$ & $\begin{array}{l}41.54 \\
* * *\end{array}$ & $\begin{array}{l}13.87 \\
*\end{array}$ & $\begin{array}{l}47.37 \\
* *\end{array}$ & $\begin{array}{l}34.66 \\
* *\end{array}$ & $\begin{array}{l}16.68 \\
*\end{array}$ & $\begin{array}{l}44.88 \\
* *\end{array}$ & $\begin{array}{l}- \\
0.78 \\
2\end{array}$ & $\begin{array}{l}- \\
0.94\end{array}$ & $\begin{array}{l}- \\
9.19 \\
*\end{array}$ & $\begin{array}{l}3.23 \\
4^{*}\end{array}$ & 1.55 & -1.62 \\
\hline 14 & $\begin{array}{l}\text { ICPH } \\
4567\end{array}$ & $\begin{array}{l}12.35 \\
*\end{array}$ & 1.47 & -0.81 & $\begin{array}{l}- \\
16.66 \\
*\end{array}$ & $\begin{array}{l}- \\
22.40 \\
* *\end{array}$ & $\begin{array}{l}- \\
18.09 \\
*\end{array}$ & $\begin{array}{l}5.49 \\
2^{*}\end{array}$ & $\begin{array}{l}2.03 \\
*\end{array}$ & 0.10 & $\begin{array}{l}2.43 \\
4\end{array}$ & 1.35 & $\begin{array}{l}- \\
2.96 \\
*\end{array}$ \\
\hline
\end{tabular}

Where, $*, * *=$ significant at $5 \%$ and $1 \%$ level of significance, respectively

Note: MPH-mid parent heterosis, BPH-better parent heterosis, SCH-Standard check heterosis (Asha)

Note: Y (kg/ha)-Yield (kg/ha), HI-Harvest index, SPC-seed protein content and DR\%-Dal recovery\% .

\section{Seed protein content:-}

Six hybrids viz., ICPH 4683 (5.95\%), ICPH 4682 (1.55\%), ICPH 4567 (1.35\%), ICPH 4680 (1.66\%), ICPH 4680 $(1.01 \%)$ and ICPH $4571(0.61 \%)$ showed positive heterosis for seed protein content over better parent. Eight hybrids showed negative heterosis viz., ICPH 4588 (-10.66\%), ICPH 4606 (-8.39\%) and ICPH 4572 (-2.48\%) showed negative heterosis for seed protein content. The range of heterobeltiosis for seed protein content varied from - 
$10.66 \%$ (ICPH 4588) to 5.95\% (ICPH 4683). For relative heterosis, nine hybrids ICPH $4683(6.230 \%)$, ICPH 4573 (3.493\%), ICPH 4682 (3.234\%), ICPH 4564 (3.068\%), ICPH 4567 (2.434\%) and ICPH 4680 (1.595\%) manifested positive heterosis for seed protein content. Although five hybrids showed negative heterosis for seed protein content, they were on par to mid-parent. Out of 14 hybrids, all hybrids showed negative heterosis for seed protein content over standard check Asha. ICPH 4746 (-3.85\%), ICPH 4571 (-3.62\%), ICPH4748 (-1.99\%), ICPH 4606 (-8.18\%), ICPH 4573 (-0.48\%), ICPH 4588 (-10.46\%), ICPH 4679 (-4.35\%), ICPH 4680 (-4.83\%), ICPH 4602 (-7.47\%) exhibited negative heterosis for seed protein content over standard check Asha.

\section{Conclusion:-}

The results obtained from present investigations concluded that. Yield point of view, the hybrid viz., ICPH 4564 and ICPH 4588 had showed positive standard heterosis for yield.So over all most of the hybrids and its component showed good impact in terms of production of hybrid seeds and yield potential of pigeonpea hybrid.

\section{Acknowledgement:-}

The author wish to acknowledge International crops research institute for the semi arid tropics (ICRISAT), Patancheru for providing financial support for research through internship.

\section{References:-}

1. Department of Agriculture and Cooperation, Ministry of Agriculture, Government of India, 2013-14.

2. Kandalkar, V.S. 2007. Evaluation of standard heterosis in advanced CMS based hybrids for grain yield, harvest index and their attributes in pigeonpea. In: Proceeding of $7^{\text {th }}$ International Conference on Sustainable Agriculture for Food, Bio-energy and Livelihood Security. 14-16 February 2007, Jabalpur, Madhya Pradesh, India. 195.

3. Sudhir kumar, Debnath, M. K., Sameer kumar, C.V., Singh,P.K., and Sultana, R. 2015.Study of heterosis and pollen fertility in CGMS based pigeonpea (Cajanus cajan (L.) Millsphaugh) hybrids. Res.Environ.Life Sci. 9(1) 107-110.

4. Saxena, K. B., 2005. Opportunities for exploiting hybrid vigour in grain legumes for increasing yield and adaptation - a success story of pigeonpea. Paper presented in 7th Annual Symposium of the Department of Agriculture, 29 - 30, September 2005, Gannoruwa, Sri Lanka. 59-76.

5. Saxena, K.B. 2006a. Seed Production systems in pigeonpea. Patancheru 502-324 Andhra Pradesh, India: International Crops Research Institute for the Semi-Arid Tropics.76.

6. Saxena, K.B., Kumar R.V., MadhaviLatha, K and Dalvi, V.A. 2006b. Commercial pigeonpea hybrids are just a few steps away. Indian J. Pulses Res. 19 (1): 7 - 16.

7. Saxena, K. B., 2008. Genetic improvement of pigeonpea- A Review. Trop. Plant Biol. 1:159-178.

8. Saxena, K. B. and Nadarajan, N., 2010. Prospects of pigeonpea hybrids in Indian agriculture.Electron. J. Plant Breed. 1 (4):1107-1117.

9. Wanjari, K.B., Bhongle, S.A and Sable, N.H. 2007. Evaluation of heterosis in CMS based hybrids in pigeonpea. J. Food Legumes. 20 (1): $107-108$.

10. Wanjari, K.B, Rathod, S.T.(2012) Exploitation of heterosis through F1 hybrid in pigeon pea (Cajanus cajan L.) Indian J. Genetics Plant Breed. 72(3);257-263.53 ref.

11. Wankhade, R.R., Wanjari, K.B., Kadam, G.M and Jadhav, B.P. 2005. Heterosis for yield and yield components in pigeonpea involving male sterile lines.Indian J. Pulses Res. 18 (2): $141-143$.

12. Yogendra Prasad, 2013, Role of genetic divergence in relation to heterosis in pigeonpea. An international quarterly journal of sciences. 8(2): 409-416, Department of Plant Breeding and Genetic, RAU, Pusa, Samastipur - 848 125,Tirhut College of Agriculture, Dholi - 843121. 